\title{
COMPARATIVE EFFICIENCIES OF VARIOUS DEHYDRAT- ING AGENTS USED FOR DRYING GASES (A SURVEY OF COMMERCIAL DRYING AGENTS)
}

\author{
By J. H. Bower
}

ABSTRACT

This paper discusses the various types of drying agents and their different modes of functioning. The method employed for determining the comparative efficiencies of the more common commercial drying agents as well as some newer drying materials recently introduced, was to aspirate properly conditioned air through a train of U-tubes containing the drying materials in the order of their increasing drying powers. After a measured amount of air had passed through the system, the increase in the weights of the U-tubes following any one U-tube indicated the residual water escaping that tube. The materials studied (with the amount of residual water in milligrams per liter of air dried), in the order of increasing efficiency at $30 \mathrm{C}$, follow: $\mathrm{CuSO}_{4}$ (anhydrous) (2.8); $\mathrm{CaCl}_{2}$ (granular) (1.5); $\mathrm{CaCl}_{2}$ ("Techincal anhydrous") (1.25); $\mathrm{ZnCl}_{2}$ (sticks) (0.98); $\mathrm{Ba}\left(\mathrm{ClO}_{4}\right)_{2}(0.82)$; $\mathrm{NaOH}$ (sticks) (0.80); $\mathrm{CaCl}_{2}$ (granular) (dehydrated) $(0.36) ; \mathrm{Mg}\left(\mathrm{ClO}_{4}\right)_{2} .3 \mathrm{H}_{2} \mathrm{O}$ (0.031); Silica Gel (0.030); $\mathrm{KOH}$ (sticks) (0.014); $\mathrm{Al}_{2} \mathrm{O}_{3}(0.005) ; \mathrm{CaSO}_{4}$ (anhydrous) (0.005); $\mathrm{CaO}$ (0.003); $\mathrm{Mg}\left(\mathrm{ClO}_{4}\right)_{2}(0.002) ; \mathrm{BaO}(0.00065)$.

\section{CONTENTS}

I. Introduction

II. Classification of agents..... 241

A. Class 1..... 241

B. Class 2

C. Class 3

D. Class 4.

E. Class 5

III. Method employed... 243

IV. Materials used

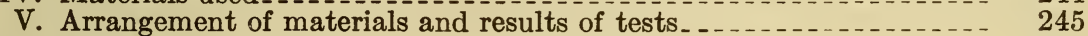

VI. Discussion of results..... 246

VII. References.... 248

\section{INTRODUCTION}

Drying agents are utilized in the laboratory for the drying of gases and liquids by direct action (contact) and for the drying of solids (and liquids) by indirect action (through the intermediary of a gas, liquid, or an evacuated space). For the purpose of discussing the action of the various types of drying agents which are commonly used in the laboratory, it will be convenient to recognize five classes.

\section{CLASSIFICATION OF AGENTS}

\section{A. CLASS 1}

Drying agents whose efficiency is determined primarily by a chemical reaction of the type:

$$
\mathrm{A}\left(\mathrm{H}_{2} \mathrm{O}\right)_{\nu} \text { (solid) }+x \mathrm{H}_{2} \mathrm{O}=\mathrm{A}\left(\mathrm{H}_{2} \mathrm{O}\right)_{x+\nu} \text { (solid). }
$$


The drying power of such an agent, when used under equilibrium conditions (for example in a desiccator) is measured by the equilibrium pressure of the water vapor, which pressure is a characteristic of the reaction at any given temperature. The corresponding limiting capacity of the drying agent per mole of $\mathrm{A}\left(\mathrm{H}_{2} \mathrm{O}\right)_{y}$ is $x$ moles of water. The practical capacity will be something less than this value. The ordinary granular calcium chloride "for desiccators" is a drying agent of this class. The reaction, applicable to the reagent used in the present work, is

$$
\mathrm{CaCl}_{2} \mathrm{H}_{2} \mathrm{O}+\mathrm{H}_{2} \mathrm{O}=\mathrm{CaCl}_{2}\left(.2 \mathrm{H}_{2} \mathrm{O}\right) .
$$

The equilibrium pressure of water vapor is $13 \mathrm{~mm} \mathrm{Hg}$ at $65 \mathrm{C}$ (19). ${ }^{1}$

\section{B. CLASS 2}

Drying agents whose efficiency is determined by a reaction of the type:

$$
\mathrm{A} \text { (solid) }+\mathrm{H}_{2} \mathrm{O}=\text { saturated solution }
$$

The drying power is measured by the equilibrium pressure of water vapor for this reaction and the drying capacity will vary inversely as the solubility of A. Common salt is a drying agent of this character. Drying agents of this class find their principal use in humidity control.

\section{CLASS 3}

Drying agents whose efficiency is determined by a reaction of the type:

$$
\mathrm{A} \text { (liq.) }+\mathrm{H}_{2} \mathrm{O}=\text { solution }
$$

The drying power of this class of drying agents decreases continuously as water is absorbed. In order to avoid this progressive decrease in drying power, drying agents of this class are usually applied in cascade or in counter-current flow. Sulphuric acid is an example of this type of drying agent.

\section{CLASS 4}

Adsorption drying agents of which silica gel is an example, depend for their drying efficiency on a large effective exposed surface together with a sufficient adsorptive capacity for water vapor. When used in a tube or tower the drying power may be very great. The drying capacity per unit surface is usually small and to be of practical value this class of drying agents must have a large effective surface. The drying capacity of a given exposed surface decreases continuously with the adsorption of water. Drying agents of this class are, therefore, usually disposed in tandem fashion as in a tube or tower, and must be renewed for each experiment. Drying agents of class A, when in granular or finely powdered condition, function partially through adsorption when used in tandem fashion and consequently may have in practice, when fresh, a higher drying power than that corresponding to the equilibrium pressure characteristic of the chemical reaction. Also a drying agent of class A may under appropriate conditions function solely as an agent of class D.

\footnotetext{
1 The numbers, 1 to 23 , in parentheses ,in the text and table refer to the references, p. 248.
} 


\section{E. CLASS 5}

Drying agents which decompose water are exemplified by the alkali and alkaline earth metals and their alloys. If the hydrogen resulting from the decomposition of the water can be continuously and completely removed, the drying power of this class of agents is practically infinite. In any case, it is determined by the partial pressure of hydrogen in the dried gas (or from the dried liquid) which is in equilibrium with a clean surface of the metal and by the value of the equilibrium constant of the reaction

$$
\mathrm{M}+\left(\mathrm{H}_{2} \mathrm{O}\right)_{x}=\mathrm{M}(\mathrm{OH})_{x}+\frac{x}{2} \mathrm{H}_{2}
$$

Three of the most important properties of drying agents for laboratory purposes are the following: (a) drying power, that is, completeness of water removal; $(b)$ drying capacity, that is, amount of water which can be removed by unit mass without loss of drying power or in some cases without decrease of drying power below some stated limit, and (c) speed of drying under the conditions of use.

Since the purpose of this survey was to compare the efficiencies of the various agents when used to dry a gas stream by a commonly used laboratory procedure, the results reported should be understood to pertain to approximately equilibrium conditions. No attempt has been made to determine the ultimate drying power, that is, the residual moisture corresponding to complete equilibrium. Where this latter information is available in the literature, however, it has been reduced to the same units and is inserted in the table for comparison. No study has been made of the capacity of the materials or limiting rates of air flow.

\section{METHOD EMPLOYED}

Properly conditioned air was aspirated through a train of U-tubes containing the desiccating materials to be studied. These materials were arranged in the order of their drying powers with the final tube or tubes containing material such as phosphorus pentoxide. The total gain in weight in all tubes following any one tube, therefore, represented the residual water escaping that tube.

In detail, the whole apparatus consisted of a constant-temperature cabinet containing a wet gas meter followed by a drying tower charged with two layers of "dehydrite" enclosing a layer of "ascarite" (NaOH-asbestos mixture). From the drying tower, connection was made to a $200 \mathrm{~mm} \mathrm{U}$-tube containing $\mathrm{Ba}(\mathrm{OH})_{2} \cdot 8 \mathrm{H}_{2} \mathrm{O}$ crystals to supply a suitable amount of water. ${ }^{1}$ This tube was followed by the $100 \mathrm{~mm}$ U-tubes (see fig. 1) containing the various desiccants. All connections beginning with the drying tower and up to the final U-tube were ground joints (fig. 1). A lubricant of negligible vapor pressure was used on these joints and all connections were coated with a layer of wax (rosin and beeswax).

The outlet of the final tube was connected, by means of heavywalled rubber tubing passing through the end of the cabinet, to a guard tube containing phosphorus pentoxide and this in turn was connected to a flask containing concentrated sulphuric acid, and, through this to a mercury manometer and a filter pump.

\footnotetext{
1 The average equilibrium pressure at $30.5^{\circ}$ was found to be about $11.3 \mathrm{~mm}$.
} 
Constant temperature was maintained by the use of two 100-watt bulbs, a bimetallic thermoregulator, ${ }^{2}$ an electric fan and a storage battery. The temperature in the cabinet was maintained at $30.5^{\circ} \pm 0.5 \mathrm{C}$ so as to be able to operate during the summer months. Runs were made only during the day, all stopcocks being closed at night. The rate of air flow varied from 1 to 5 liters per hour in most experiments. The internal pressure of the system was determined in each case. However, corrections for differences in the volumes of air entering and leaving the system were found to be negligible.

\section{MATERIALS USED}

Except as otherwise noted the materials studied were commercial products in the form in which they were marketed as drying agents. In most cases they are identified below only by information taken from the label of the container. In some instances, however, a partial analysis was made and the results are indicated. Before use, certain of the drying agents were first subjected to a dehydrating treatment

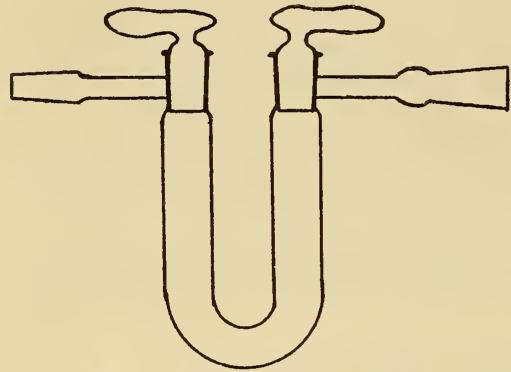

FUIGRe 1.-Type of U-tube employed. corresponding to that normally employed in preparing them for use or in regenerating them. Such treatments are indicated in each instance.

"Anhydrous Copper Sulphate" was the "C.P." powder. Analysis gave 92.5 percent of $\mathrm{CuSO}_{4}$. The tube of copper sulphate was heated to $250 \mathrm{C}$ for 2 hours while passing through it air dried by phosphorus pentoxide. "Calcium Chloride (Granular)" was labeled "anhydrous (dried) granular for drying tubes," and was of 8-mesh fineness. The analysis showed the average composition to correspond approximately to $\mathrm{CaCl}_{2} \cdot \mathrm{H}_{2} \mathrm{O}$. "Calcium Chloride (Technical Anhydrous)" was found by analysis to have an average composition corresponding to the formula $\mathrm{CaCl}_{2} \cdot \frac{1}{4} \mathrm{H}_{2} \mathrm{O}$. "Zinc Chloride (Sticks)" was the "C.P." material. Analysis showed 97.9 percent of $\mathrm{ZnCl}_{2}$. "Barium Perchlorate (Anhydrous)" or "Desicchlora" was a commercial product and was in the form of irregularly shaped lumps varying in size. "Sodium Hydroxide (Sticks)" was the "C.P." material. The analysis showed 97.1 percent of $\mathrm{NaOH}$ and 0.6 percent of $\mathrm{Na}_{2} \mathrm{CO}_{3}$. It was crushed to a coarse powder for use. "Calcium Chloride (Anhydrous)" was the granular calcium chloride previously described, which had been heated to 250 to $275 \mathrm{C}$ in the $\mathrm{U}$-tube, while passing through it air dried by phosphorus pentoxide. The dry air was followed by dry carbon dioxide to neutralize any basic compounds present. "Magnesium Perchlorate-Trihydrate" or "Dehydrite" was a commercial product and was in a coarsely granular form. "Silica Gel" was a granular commercial product passing a no. 60 and retained on a no. 200 sieve. Analysis showed 11.3 percent of water and 0.4 percent of impurities (iron, etc.). It was prepared for use by heating in the U-tube at 110 to $130 \mathrm{C}$, in vacuo, for 5 hours. "Potassium Hydroxide" was the U.S.P. material in stick form. Analysis showed 81.9 percent of $\mathrm{KOH}$ and 1.3 percent of $\mathrm{K}_{2} \mathrm{CO}_{3}$. It was crushed to a coarse powder for

${ }^{2}$ Later in the investigation this was replaced by a mercury thermostat. 
use. "Aluminum Trioxide" was a commercial product known as "Hydralo". It was similar in form to granular calcium chloride. Analysis showed it to be mainly $\mathrm{Al}_{2} \mathrm{O}_{3}$ with about 11 percent of water. The U-tube containing the "hydralo" was heated in a bath at 150 to $180 \mathrm{C}$ for 6 hours while passing through it air dried by phosphorus pentoxide. "Calcium Sulphate, Anhydrous (Soluble Anhydrite)" was prepared from the dihydrate $\mathrm{CaSO}_{4} .2 \mathrm{H}_{2} \mathrm{O}$, which was obtained through the courtesy of James $\mathrm{R}$. Withrow. It was in granular form of $y_{10}$ to $1 / 20$ inch (no. 7 to no. 15 sieve) fineness. The U-tube containing the dihydrate was heated to 220 to $230 \mathrm{C}$ for 2 hours while passing through it air dried by phosphorus pentoxide. The loss in weight indicated that practically all water had been removed. "Calcium Oxide" was the C.P. reagent in powderedform. It was heated to redness (600 to $650 \mathrm{C}$ ) for 4 hours and cooled in a desiccator over barium oxide before use. "Magnesium Perchlorate (Anhydrous)", or "Anhydrone" was a commercial product in the form of small lumps of varying size. It was obtained through the courtesy of G. F. Smith. "Barium Oxide" was a specially prepared product obtained through the cooperation of H. S. Booth. It was in a uniformly granular form of $1 / 10$ to $1 / 20$ inch (no. 7 to no. 15 sieve) fineness.

\section{ARRANGEMENT OF MATERIALS AND RESULTS OF TESTS}

The arrangements of the trains of drying agents in the various tests were as follows, with the material, for which the report is made underlined in each case:

1. $\mathrm{Ba}(\mathrm{OH})_{2} .8 \mathrm{H}_{2} \mathrm{O}-\mathrm{CuSO}_{4}-\mathrm{Mg}\left(\mathrm{ClO}_{4}\right)_{2} .3 \mathrm{H}_{2} \mathrm{O}-\mathrm{Mg}\left(\mathrm{ClO}_{4}\right)_{2}$

2. $\mathrm{Ba}(\mathrm{OH})_{2} .8 \mathrm{H}_{2} \mathrm{O}-\overline{\mathrm{CaCl}_{2}}$ (gran.) $-\mathrm{NaOH}-\mathrm{Mg}\left(\mathrm{ClO}_{4}\right)_{2} .3 \mathrm{H}_{2} \mathrm{O}$

3. $\mathrm{Ba}(\mathrm{OH})_{2} .8 \mathrm{H}_{2} \mathrm{O}-\mathrm{CaCl}_{2}$ (tech. anh.) $-\mathrm{CaSO}_{4}-\mathrm{P}_{2} \mathrm{O}_{5}$

4. $\mathrm{Ba}(\mathrm{OH})_{2} \cdot 8 \mathrm{H}_{2} \mathrm{O}-\mathrm{ZnCl}_{2}-\mathrm{Mg}\left(\mathrm{ClO}_{4}\right)_{2} \cdot 3 \mathrm{H}_{2} \mathrm{O}^{3}$

5. $\mathrm{Ba}(\mathrm{OH})_{2} .8 \mathrm{H}_{2} \mathrm{O}-\overline{\mathrm{Ba}\left(\mathrm{ClO}_{4}\right)_{2}} .{ }^{4}-\mathrm{P}_{2} \mathrm{O}_{5}$

6a. $\mathrm{Ba}(\mathrm{OH})_{2} .8 \mathrm{H}_{2} \mathrm{O}-\mathrm{CaCl}_{2}$ (gran.) $-\mathrm{NaOH}-\mathrm{Mg}\left(\mathrm{ClO}_{4}\right)_{2} \cdot 3 \mathrm{H}_{2} \mathrm{O}-\mathrm{KOH}$ $-\mathrm{P}_{2} \mathrm{O}_{5}$

6b. $\mathrm{Ba}(\mathrm{OH})_{2} \cdot 8 \mathrm{H}_{2} \mathrm{O}-\mathrm{CaCl}_{2}$ (gran.) $-\mathrm{NaOH}-\mathrm{KOH}-\mathrm{Mg}\left(\mathrm{ClO}_{4}\right)_{2}$

7a. $\mathrm{Ba}(\mathrm{OH})_{2} \cdot 8 \mathrm{H}_{2} \mathrm{O}-\mathrm{CaCl}_{2}$ (anh.) $-\overline{\mathrm{Mg}\left(\mathrm{ClO}_{4}\right)_{2}}-\mathrm{P}_{2} \mathrm{O}_{5}$

7b. $\mathrm{Ba}(\mathrm{OH})_{2} \cdot 8 \mathrm{H}_{2} \mathrm{O}-\overline{\mathrm{CaCl}}$ (anh.) $-\mathrm{CaSO}_{4}-\mathrm{Mg}\left(\mathrm{ClO}_{4}\right)_{2}-\mathrm{P}_{2} \mathrm{O}_{5}$

8. $\mathrm{Ba}(\mathrm{OH})_{2} .8 \mathrm{H}_{2} \mathrm{O}-\mathrm{Mg}\left(\mathrm{ClO}_{4}\right)_{2}-3 \mathrm{H}_{2} \mathrm{O}-\mathrm{CaSO}_{4}-\mathrm{Mg}\left(\mathrm{ClO}_{4}\right)_{2}-\mathrm{P}_{2} \mathrm{O}_{5}$

9. $\mathrm{Mg}\left(\mathrm{ClO}_{4}\right)_{2} \cdot 3 \mathrm{H}_{2} \mathrm{O}$-silica gel- $\mathrm{Al}_{2} \mathrm{O}_{3}-\mathrm{P}_{2} \mathrm{O}_{5}$

10. $\mathrm{Ba}(\mathrm{OH})_{2} \cdot 8 \mathrm{H}_{2} \mathrm{O}-\overline{\mathrm{Mg}\left(\mathrm{ClO}_{4}\right)_{2}} \cdot 3 \mathrm{H}_{2} \mathrm{O}-\mathrm{KOH}-\mathrm{Mg}\left(\mathrm{ClO}_{4}\right)_{2}{ }^{5}$

11. $\mathrm{Mg}\left(\mathrm{ClO}_{4}\right)_{2} \cdot 3 \mathrm{H}_{2} \mathrm{O}$-silica gel- $-\mathrm{Al}_{2} \mathrm{O}_{3}-\overline{\mathrm{P}}_{2} \mathrm{O}_{5}$

12a. $\mathrm{CaCl}_{2}$ (gran.)-silica gel-Ca $\overline{\mathrm{SO}_{4}}-\mathrm{P}_{2} \mathrm{O}_{5}$

12b. $\mathrm{Ba}(\mathrm{OH})_{2} \cdot 8 \mathrm{H}_{2} \mathrm{O}-\mathrm{CaSO}_{4}-\overline{\mathrm{P}_{2} \mathrm{O}_{5}}$

13. $\mathrm{CaCl}_{2}$ (gran.) $-\mathrm{CaO}-\mathrm{P}_{2} \mathrm{O}_{5}$

14a. $\mathrm{Ba}\left(\mathrm{ClO}_{4}\right)_{2}-\overline{\mathrm{Mg}\left(\mathrm{ClO}_{4}\right)_{2}-\mathrm{Mg}\left(\mathrm{ClO}_{4}\right)_{2}}-\mathrm{P}_{2} \mathrm{O}_{5}$

14b. $\mathrm{Al}_{2} \mathrm{O}_{3}-\mathrm{Mg}\left(\mathrm{ClO}_{4}\right)_{2}-\mathrm{P}_{2} \mathrm{O}_{5}$

15. $\mathrm{Ba}(\mathrm{OH})_{2} .8 \mathrm{H}_{2} \mathrm{O}-\mathrm{BaO}^{6}-\mathrm{P}_{2} \mathrm{O}_{5}$

Results are summarized in table 1 and shown graphically in figure 2.

3 Correction made for residual water from $\mathrm{Mg}\left(\mathrm{ClO}_{4}\right) .3 \mathrm{H}_{2} \mathrm{O}$.

1 A straight tube $30 \mathrm{~cm}$ by $1.75 \mathrm{~cm}$ was substituted for the U-tube.

3 Correction made for residual water from $\mathrm{Mg}\left(\mathrm{ClO}_{4}\right)^{2}$.

${ }^{6}$ A straight tube $30 \mathrm{~cm}$ by $1.75 \mathrm{~cm}$ was substituted for the U-tube. 
TABLE 1.-Results of tests

\begin{tabular}{|c|c|c|c|c|c|}
\hline $\begin{array}{l}\text { Number } \\
\text { of tests }\end{array}$ & Material & $\begin{array}{l}\text { Volume of } \\
\text { air per } \\
\text { hour per } \\
\text { ml desic- } \\
\text { cant (ml) }\end{array}$ & $\begin{array}{l}\text { Total vol- } \\
\text { ume of air } \\
\text { per ml of } \\
\text { desiccant (1) }\end{array}$ & $\begin{array}{l}\text { Residual water per } \\
\text { liter of air }(\mathrm{mg})\end{array}$ & $\begin{array}{l}\text { Values from published } \\
\text { data }(\mathrm{mg} / \mathrm{l})\end{array}$ \\
\hline 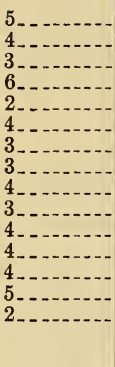 & 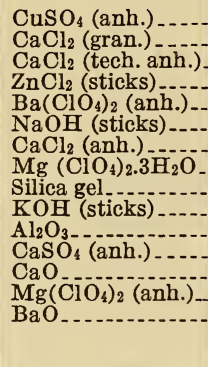 & $\begin{array}{r}36 \text { to } 50 \\
66 \text { to } 165 \\
115 \text { to } 150 \\
120 \text { to } 335 \\
26 \text { to } 36 \\
75 \text { to } 170 \\
75 \text { to } 240 \\
65 \text { to } 160 \\
65 \text { to } 135 \\
55 \text { to } 65 \\
65 \text { to } 135 \\
75 \text { to } 150 \\
60 \text { to } 90 \\
95 \text { to } 130 \\
64 \text { to } 66\end{array}$ & $\begin{array}{r}0.45 \text { to } 0.7 \\
6.1 \text { to } 24.2 \\
4.0 \text { to } 5.8 \\
.8 \text { to } 2.1 \\
2.3 \text { to } 3.7 \\
2.3 \text { to } 8.9 \\
1.2 \text { to } 7.8 \\
4.0 \text { to } 7.2 \\
6.5 \text { to } 7.7 \\
3.2 \text { to } 7.2 \\
6.5 \text { to } 7.7 \\
1.2 \text { to } 18.5 \\
7.6 \text { to } 10.1 \\
6.4 \text { to } 13.2 \\
10.6 \text { to } 25\end{array}$ & $\begin{array}{l}2.8(2.7 \text { to } 2.9) \\
1.5(1.4 \text { to } 1.6) \\
1.25(1.23 \text { to } 1.27) \\
0.98(0.94 \text { to } 1.02) \\
0.82(0.76 \text { to } 0.88) \\
0.80(0.78 \text { to } 0.83) \\
0.36(0.33 \text { to } 0.38) \\
0.031(0.028 \text { to } 0.033) \\
0.03(0.02 \text { to } 0.04) \\
0.014(0.010 \text { to } 0.017) \\
0.005(0.004 \text { to } 0.009) \\
0.005(0.004 \text { to } 0.006) \\
0.003(0.003 \text { to } 0.004) \\
0.002(0.002 \text { to } 0.003) \\
0.00065(0.0006 \text { to } 0.0008)\end{array}$ & $\begin{array}{l}1.7 \text { at } 30 \mathrm{C}(7) . \\
0.95 \text { at } 30 \mathrm{C}(4) . \\
0.29 \text { at } 27 \mathrm{C}(19) . \\
0.16 \text { at } 25 \mathrm{C}(2) . \\
0.36 \text { at } 25 \mathrm{C}(3) . \\
0.002 \text { at } 25 \mathrm{C}(2) . \\
0.003 \text { at } 25(7) \text {. } \\
0.005 \text { at } 25(10) . \\
0.2 \text { to } 0.3 \text { at } 25 \mathrm{C}(7) . \\
(20) . \\
\text { Less than } 0.0003 \text { at, } \\
\text { "ordinary temp." } \\
\text { (5). }\end{array}$ \\
\hline
\end{tabular}

1 Numbers in parentheses refer to "References", p. 248.

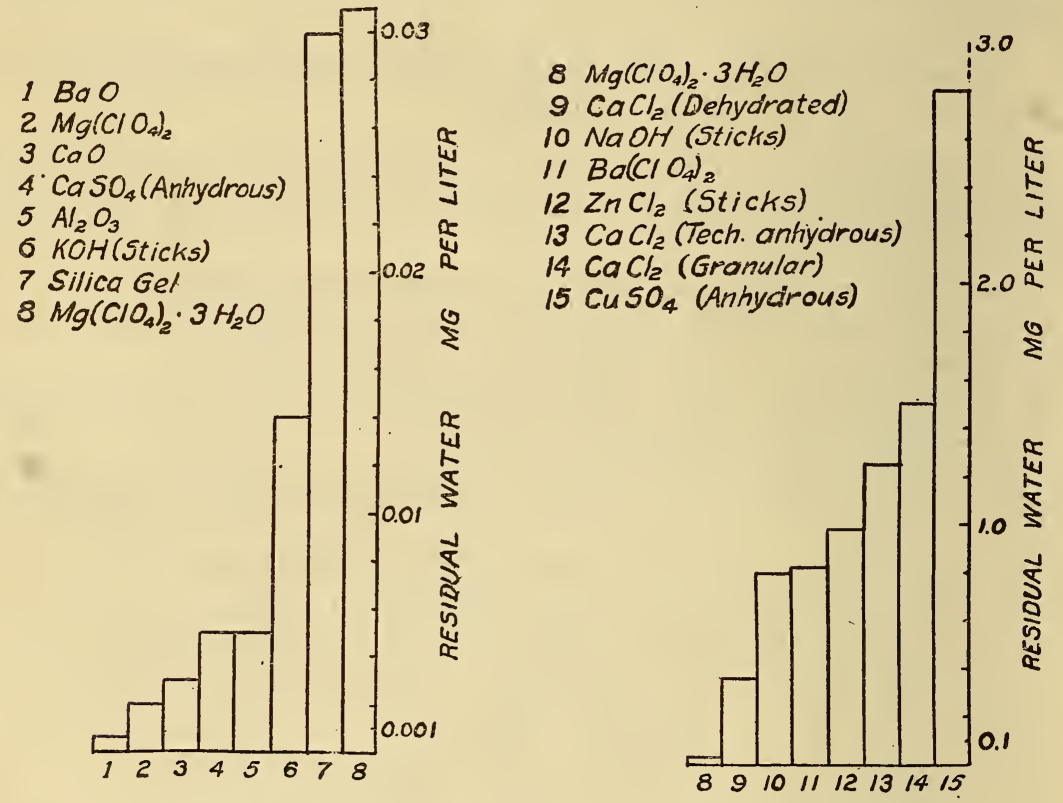

FIGURE 2.-Graphical representation of comparative efficiencies.

\section{DISCUSSION OF RESULTS}

Previous investigations of the efficiency of dehydrating agents have been made, almost without exception, at one or more of the three temperatures, 0,25 , and $50 \mathrm{C}$, and therefore comparisons between the results obtained in the present work and those obtained in previous investigations can be made only by estimation. Such comparisons show agreement in some cases but in others there is a marked variation, attributable in the cases of anhydrous copper sulphate, sodium hydroxide, and potassium hydroxide, to the fact that in the 
present investigation the regular stock reagents were used, whereas previous investigators used specially prepared materials.

In the case of calcium oxide an efficiency was found which is nearly 100 times as great as that reported in the literature (7). The efficiency will be greatly reduced if it contains even small amounts of silicates and aluminates which melt and form a glaze over the particles when the lime is burned.

The efficiency of "dehydrite" reported in the literature (21) is somewhat lower than was obtained in the present work. This may be largely because of differences in the rate of gas flow.

There has been confusion in the reported efficiency of calcium chloride, largely because of a difference in the materials studied. The equilibrium pressures for the "lowest hydrate" of calcium chloride have been reported to be $0.29 \mathrm{~mm}, 2.17 \mathrm{~mm}$, and $3.50 \mathrm{~mm}$ at 0,24 , and $30 \mathrm{C}$ respectively (6). According to Baxter and Starkweather (2) W. F. Hillebrand called their attention to the fact that these pressures applied to the hydrate containing 26 percent of water. This would correspond to the dihydrate. In the present investigation the granular calcium chloride first studied was approximately the monohydrate with equilibrium pressure of about $1.6 \mathrm{~mm}$ at $30.5 \mathrm{C}$ while the equilibrium pressure for anhydrous calcium chloride (the ordinary granular calcium chloride after heating to $260-275 \mathrm{C}$ ) is reported to be from 0.14 to $0.25 \mathrm{~mm}$ at $25 \mathrm{C}(14)$. The present tests of the anhydrous salt (table 1) indicate a pressure of about $0.38 \mathrm{~mm}$ at $30.5 \mathrm{C}$.

"Anhydrone" is reported as leaving no weighable residual water after passing 210 liters of air through it at $25 \mathrm{C}(21)$. The rate of air flow was 65 to $152 \mathrm{ml}$ per hour per $\mathrm{ml}$ of desiccant. In the present investigation, the rate of air flow varied from 95 to $130 \mathrm{ml}$ per hour per $\mathrm{ml}$ of desiccant and the volume of air used in the 5 tests varied from 128 to 263 liters. At $30^{\circ}$ weighable amounts of residual water were found in all cases.

Barium oxide is reported as leaving less than $0.0003 \mathrm{mg}$ of residual water per liter of gas dried at ordinary temperatures (5). In the present work the amount of residual water at $30.5 \mathrm{C}$ was $0.0005-$ $0.0008 \mathrm{mg}$. In view of the fact that "ordinary temperatures" may include a temperature as much as $10^{\circ}$ lower than that at which the present tests were made, the agreement between results seems fairly good.

"Desicchlora" is reported as leaving $0.29 \mathrm{mg}$ of residual water per liter after drying 198 liters of gas at a rate of $233 \mathrm{ml}$ per hour per $\mathrm{ml}$ of desiccant and $0.42 \mathrm{mg}$ of water per liter after drying 110 liters at a rate of $356 \mathrm{ml}$ per hour per $\mathrm{ml}$ of desiccant (20). The temperature in both cases was 27 to $27.5 \mathrm{C}$. The dimensions of the drying column were 30.5 by $2.54 \mathrm{~cm}$. In the present investigation the amount of air dried was 167 liters at a rate of $36 \mathrm{ml}$ per hour per $\mathrm{ml}$ of desiccant and 263 liters at a rate of $26 \mathrm{ml}$ per hour per ml of desiccant, leaving 0.88 and $0.76 \mathrm{mg}$ of residual water per liter, respectively. The dimensions of the column of "desicchlora" were approximately 30 by $1.75 \mathrm{~cm}$ and the temperature was the same as used throughout, viz, $30.5 \mathrm{C}$.

Aluminum trioxide is stated in the literature to leave no residual water in gas passed through it at 18 or $20 \mathrm{C}$ until it has taken up 18 percent of its own weight. Another investigator reports $0.003 \mathrm{mg}$ of residual water per liter of air at $25 \mathrm{C}(7)$. The material used in this 
investigation, viz, "Hydralo", after a reactivation treatment, was found to have an efficiency in fair agreement with one previously reported (7). Without the preliminary heat treatment the efficiency was very much lower.

This work was done at the suggestion, and under the direction of, E. W. Washburn, chief of the chemistry division of the Bureau of Standards.

\section{REFERENCES}

1. Barnitt, J. B., Derr, R. B., and Scripture, E. W., Ind. Eng. Chem., Anal. Ed., vol. 2, no. 4, p. 355, 1930.

2. Baxter, G. P., and Starkweather, H. W., Jour. Am. Chem. Soc., vol. 38, p. 2038, 1916.

3. Baxter, G. P., and Starkweather, H. W., Jour. Am. Chem. Soc. vol. 38, p. 2041, 1916.

4. Baxter, G. P., and Warren, R. D., Jour. Am. Chem. Soc., vol. 33, p. 344, 1911.

5. Booth, H. S., and McIntyre, L. H., Ind. Eng. Chem., Anal. Ed., vol. 2, no. 1 , p. $12,1930$.

6. Dibbits, H. C., Anal. Chem. vol. 15, p. 159, 1876.

7. Dover, M. V., and Marden, J. W., Jour. Am. Chem. Soc., vol. 39, p. 1613, 1917.

8. Dover, M. V., and Marden, J. W., Jour. Am. Chem. Soc., vol. 39, p. 1609, 1917.

9. Elder, A. L., and Brandes, O. L., Jour. Phys. Chem., vol. 35, pp. 3022-4, 1931.

10. Hammond, W. A., and Withrow, J. R., Ind. Eng. Chem., vol. 25, p. 653, 1933.

11. Johnson, F. M. G., Jour. Am. Chem. Soc., vol. 34, p. 911, 1912.

12. Marden, J. W., and Elliott, V., Jour. Ind. Eng. Chem., vol. 7, p. 320, 1915.

13. McGavack, J., and Patrick, W. A., Jour. Am. Chem. Soc., vol. 42, p. 946, 1920.

14. McPherson, A. T., Jour. Am. Chem. Soc., vol. 39, p. 1319, 1917.

15. Miller, E. B., Chem. \& Met. Eng., vol. 23, p. $1221,1920$.

16. Moles, E., and Roquero, C., Anales soc. espan. fis. quim., vol. 31, p. 11, 1933.

17. Morley, E. W., Am. Jour. Sci., vol. 34, p. 199, 1887, Ibid, Jour. Am. Chem. Soc., vol. 26, p. 1171, 1904.

18. Munroe, L. A., and Johnson, F. M. G., Ind. Eng. Chem., vol. 17, p. 88, 1925.

19. Roozeboom, 2, Physik. Chem. vol. 4, p. 31, 1889.

20. Smith, G. F., Ind. Eng. Chem., vol. 19, p. 411, 1927.

21. Willard, H. H., and Smith, G. F., Jour. Am. Chem. Soc., vol. 44, p. 2255, 1922.

22. Willard, H. H., and Smith, G. F., Ind. Eng. Chem., vol. 16, p. 20, 1924.

23. Yoe, J. H., Chem. News, vol. 130, p. 340, 1924.

Washington, July 13, 1933. 